\title{
MATERIAL MEMORIES OF THE GUILDSMEN. CRAFTING IDENTITIES IN EARLY MODERN LONDON
}

\author{
Jasmine Kilburn-Toppin
}

In July 1528, William Vynyard, former master and major benefactor of the Armourers' guild of London donated to his fellow guildsmen a polychromed oak sculpture of St George, patron saint of the company (figure 9). Standing at just under a metre high and clad in miniature iron armour which had been crafted in the workshop of Vynyard himself, the sculpture was set before the high table in the Armourers' communal Hall, the highlight of a broader visual and material culture of devotion and memorialisation. ${ }^{1}$ The Armourers' model of St George, a virtuoso piece of craftsmanship, was retained by the guild throughout the early modern era. A rare pre-Reformation survival, this sculpture is still in situ within the institutional home of its maker. ${ }^{2}$ As one of the Armourers' most prized corporate possessions in the sixteenth and seventeenth centuries, the sculpture played an active role in the rich ceremonial life of the guildsmen - within and outside the Armourers' Hall-and became the founding piece in a large collection of miniaturised and full-sized suits, all of which were connected to the workshops and memory of significant makers and guildsmen.

Within the late-medieval craft fraternities and early modern guilds of London, the gifting of material culture for display in livery halls, and use in company rituals, was a significant means for guildsmen to establish reputations in life and uphold memory within the craft community after death. Though the Reformation swept away the intercessory value of material objects, physical things continued to act as significant prompts for the memorialisation of a guildsman's achievements, skills and qualities in life. In the following chapter, material gifts and bequests by craftsmen

\footnotetext{
1 William Vynyard was master of the Armourers' Company on three separate occasions: 1503-04, 1513-14 and 1531-32.

${ }^{2}$ For the devastating consequences of iconoclasm upon English sculpture survival, see: Richard Deacon and Phillip Lindley, Image and idol. Medieval sculpture (London: Tate, 2001).
} 


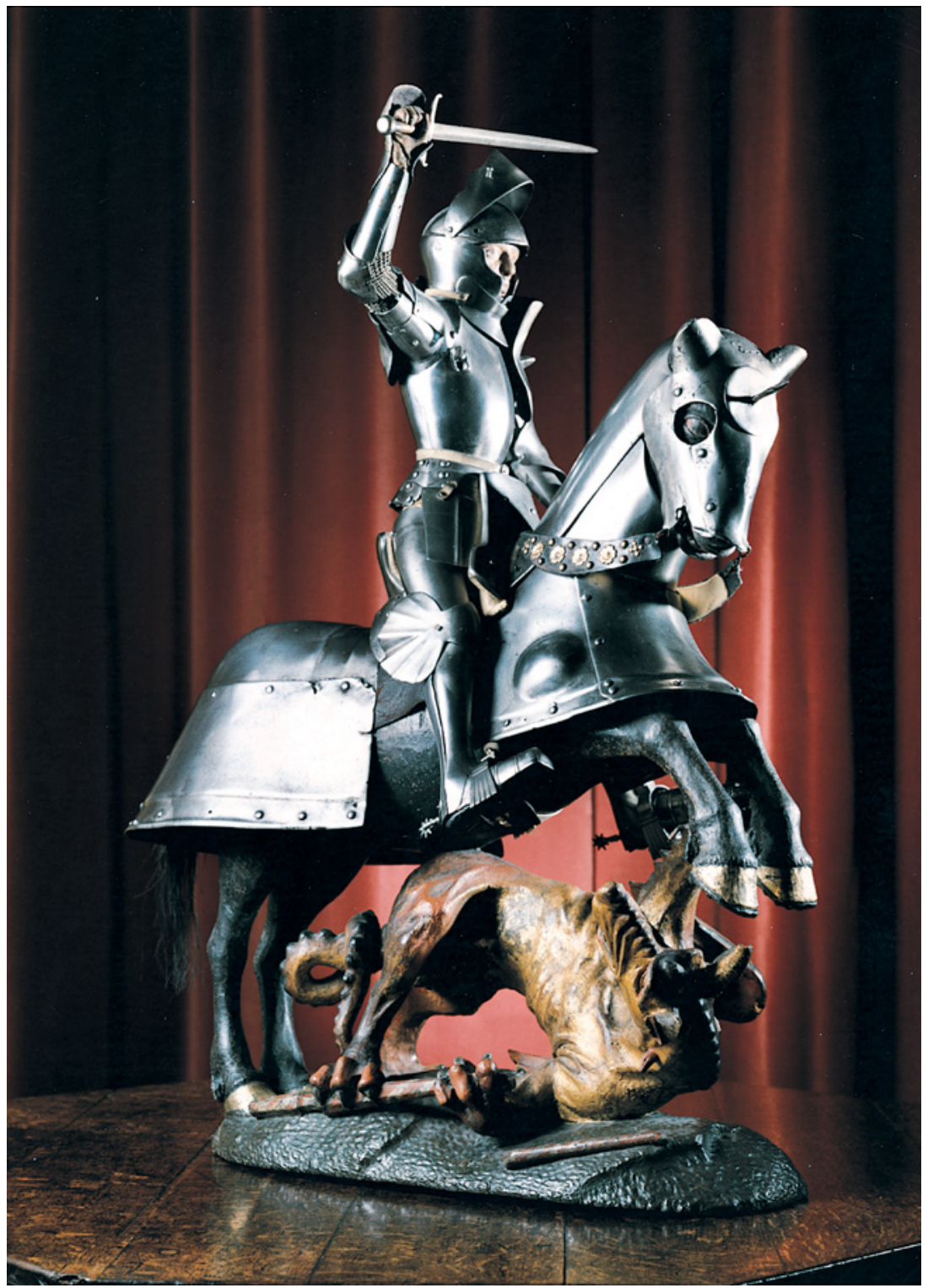

Fig. 9. St George and the Dragon, c. 1528, polychromed oak, iron, leather and horse hair, Armourers' Company, London. 
to their guilds are considered as dynamic bearers of personal and communal memory and cultural identity across the early modern period. Though objects had particular meanings or resonances at the point of donation, these material 'things' also continued to have active social and ritual lives for many decades beyond, thus perpetuating the memory of the dead within the community of living guildsmen. ${ }^{3}$ Therefore in contrast to the existing historiography of English civic institutions, which has proposed a decisive shattering of time-honoured cultures of collective memory in the wake of the Reformation, this chapter will suggest that within the early modern artisanal guild, memory cultures displayed aspects of continuity, as well as change. ${ }^{4}$ Fundamentally, the communal identity of a craft guild as an association of skilled makers of physical things had a bearing on how individuals shaped their post-mortem reputations. Particular materials, tools and visual representations of accomplished artisanal labour were significant foundations in the construction of personal and collective memories within the political and social body which constituted a London livery company.

The guilds of early modern London originated from late-medieval craft fraternities. These associations of craftsmen were bound together through mutual economic regulation and support, shared standards of respectability and dedication to a patron saint; usually a figure specifically associated with their particular workshop practice. ${ }^{5}$ As one of the most revered warrior saints throughout Christendom-allegedly an army officer who was martyred in the late third or early fourth centuries - the chivalric, crusading St George was naturally a favourite among armourers' guilds across Europe, and the London Armourers were no exception. ${ }^{6}$ The

3 Arjun Appadurai, 'Introduction. Commodities and the politics of value', in his The social life of things. Commodities in cultural perspective (Cambridge: Cambridge University Press, 1986), 3-63.

4 Robert Tittler, 'Reformation, civic culture and collective memory in English provincial towns', Urban History 24 (1997), 283-300; Robert Tittler, The reformation and the towns in England: politics and political culture, c. 1540-1640 (Oxford: Clarendon Press, 1998); Victor Morgan, 'The construction of civic memory in early modern Norwich', in Marius Kwint, Christopher Breward and Jeremy Ansley (eds.), Material memories (Oxford: Berg, 1999), $183-197$.

5 George Unwin, The gilds and companies of London (4th ed., London: Frank Cass, 1966), 93-126; Gervase Rosser, 'Crafts, guilds and the negotiation of work in the medieval town', Past and Present 154 (1997), 3-31.

6 Jonathan Bengtson, 'Saint George and the formation of English nationalism', Journal of Medieval and Early Modern Studies 27 (1997), 317-340; Muriel C. McClendon, 'A moveable feast. Saint George's Day celebrations and religious change in early modern England', Journal of British Studies 38 (1999), 1-27. 
Goldsmiths' guild revered the figure of St Dunstan, said to be a skilled tenth-century Glastonbury metalworker. ${ }^{7}$ As bodies which nourished the spiritual, as well as social and economic needs of their members, these craft fraternities were deeply involved in the 'cult' of the dead: the rich culture of memorialisation, centred on a belief in Purgatory, which bound living and dead communities together through perpetual cycles of masses, indulgences and fasts. ${ }^{8}$ A collective memory culture in which visual and material representations, signs or embodiments of the Holy Family and 'heavenly society' of saints acted as essential-if not entirely uncontroversial-intercessory tools. ${ }^{9}$ Crucially, the late-medieval craft fraternities provided lights in honour of their patron saints, and the memory of departed brothers; they organised alms, prayers and funerals for their members and on significant days in the ritual calendar, hosted feasts for the advancement of commensality and charity amongst the living brethren. ${ }^{10}$ The London Armourers' guild acquired the advowson of a chantry dedicated to St George in the Chapel of St Thomas in St Paul's Cathedral in the first half of the fifteenth century and were not unusual-among craft institutions in the city-in maintaining such perpetual supplications to their patron saint." ${ }^{11}$ The mercantile guilds with the wealthiest members and largest endowments supported multiple intercessory services at any one time; the Guild of the Merchant Taylors of the Fraternity of St John the Baptist funded nine chantry priests and an additional fourteen obits. ${ }^{12}$

Craft fraternities usually had close associations with city churches in the same streets and parishes as their guild halls, and it was in these spaces

7 Douglas Dales, 'Saint Dunstan, patron saint of goldsmiths', in Timothy Schroder (ed.), Treasures of the English church. A thousand years of sacred gold and silver (London: Goldsmiths' Company in association with Paul Holberton Pub., 2008), 11-15.

8 Eamon Duffy, The stripping of the altars. Traditional religion in England, c. 1400-c. 1580 (2nd ed., New Haven and London: Yale University Press, 2005), 301-302.

9 For a recent analysis of the ambivalent [or 'paradoxical'] relationship between materiality and devotional objects in a pre-Reformation context, see: Caroline Walker Bynum, Christian materiality. An essay on religion in late medieval Europe (New York: Zone Books, 2011).

10 Duffy, The stripping of the altars, 142-144; Barbara Hanawalt, " Keepers of the light". Late medieval English parish gilds', Journal of Medieval and Renaissance Studies, 14 (1984), 26-37; Gervase Rosser, 'Going to the fraternity feast. Commensality and social relations in late medieval England', Journal of British Studies 33 (1994), 430-446.

11 Elizabeth Glover, Men of metal. History of the Armourers and Brasiers of the City of London (Huddersfield: Jeremy Mills for The Worshipful Company of Armourers and Brasiers, 2008), 24.

12 Charles M. Clode, Memorials of the Guild of Merchant Taylors of the Fraternity of St. John the Baptist, in the City of London (London: Harrison \& Sons, 1875), 84-92. 
that members' funerals were held, and prominent brothers buried and memorialised. In the late sixteenth-century Survey of London, the historian John Stow revealed some of the significant connections between medieval craft fraternities, places of workshop and memorialisation of members. In the ward of Aldersgate, the site of the Goldsmiths' Company Hall, lay the church of St John Zachary, which many brothers of the fraternity had sponsored and were subsequently remembered within: 'A fayre church, with the monuments wel[l] preserved, of Thomas Lichfield who founded a chauntrie there ... Nicholas Twiford, Goldsmith, mayor 1388 . . of whose goods the church was made and new builded, with a tomb for them and others of their race...' (and so the list continues, naming nearly a dozen significant goldsmiths).$^{13}$ In the parish church of St Leonard, located on the same lane as the Goldsmiths' Hall, there was a monument to Robert Trappis, a goldsmith, who died in $15^{26}$, with an epitaph which deliberately played with notions of memorialisation or remembrance: 'When the bel[l]s be merily roong, And the masse devoutly sung, And the meat merily eaten, Then shall Robert Traps his wives And children be forgotten'. ${ }^{14}$ The goldsmith Henry Coote, who passed away in 1513, left seventy pounds to St Dunstan's chapel in the church of St Vedast, for the rebuilding of the chapel and a glass window 'to be made according to a pattern I have caused to be made containing the life of St Dunstan and the figures of me and my two wives'. ${ }^{15}$

Inventories compiled by late-medieval craft guilds show that members established their identities or reputations in life and memory after death, through the donation of material goods and furnishings for neighbouring churches and their institutional homes, the livery halls. An inventory taken in 1490 by the 'bretherhode of the assumpcion of our Blessid Lady of the crafte of pewter of London', a list of gifts donated and bequeathed to the guild by its members, records textiles, silver plate and torches or lights, items which were linked specifically to the performance of Eucharistic worship, 'a much favoured way of securing remembrance'. ${ }^{16}$ Guildsmen also gave the essential material apparatus for carrying out the funerals of brothers of the fraternity, such as 'a bla[c]k cofyn with iii chapelet[s] of

13 John Stow, A survey of London, ed. Charles Lethbridge Kingsford, 2 vols. (Oxford: Oxford University Press, 1908), vol. 1, 305.

14 Ibid.

15 Thomas F. Reddaway and Lorna E. Walker, The early history of the Goldsmiths' Company, 1327-1509 (London: Edward Arnold, 1975), 293.

16 Pewterers' Company, 'Inventories 1490-1838', MS 7110, Guildhall Library, London; Duffy, The stripping of the altars, 331. 
red saten with the ymage of our lady assumpcion of sylver'. ${ }^{17}$ Silver and pewter plate such as apostle spoons, cups and bowls, and textiles such as table and banner cloths, were also given to the craft for the performance of commemorative funeral feasts, dinners and civic processions which punctuated the ritual calendar of the guild; most significant was the election of the new master and wardens (which was usually held on the patronal feast day). This was an event to which members of the civic elite (from outside the specific guild) might be invited, and thus a valuable opportunity for observing ritual practices and interior furnishings of rival companies. The end of the annual election process was marked by a church service on the Sunday following the election feast, during which a mass requiem for the dead members was heard, prayers were made for the departed and the priest said a prayer for the entire surviving brotherhood 'naming each individual separately by name'. ${ }^{18}$ The Pewterers' inventory also shows that guildsmen materialised their memory within the company Hall through the sponsorship of windows; in 1494, seventeen individual guildsmen paid for the glazing of window panels in the hall, including a bay window and 'the high window over the high dais', using 'flemysshe' and 'normandy' glass. ${ }^{19}$ Coloured glass panes bearing benefactors' arms were also installed in the fifteenth-century halls of the Carpenters' and Merchant Taylors' Companies. ${ }^{20}$ Guildsmen took care to ensure that their heraldry was displayed in the most prominent spaces, and thus after death, their memory (and that of their ancestors), would be associated with political prestige within the guild. ${ }^{21}$

This culture of collective memorialisation within the London guilds was undoubtedly disrupted by the Reformation, specifically by the injunctions of the 1540 , which outlawed fraternities, chantries, the provision and performance of obits and the burning of lights. ${ }^{22}$ Fundamentally, craft guilds were no longer permitted to perform intercessory acts on behalf of dead members of the brotherhood. But though the traditional 'cult of the dead' had been undermined, the guild institutions themselves, as economic,

17 MS 7110, f. 2v.

18 William Herbert, The history of the twelve great livery companies of London, 2 vols. (London: William Herbert, 1837), vol. 1, 68-69.

19 MS 7110, f. 4v.

20 John Schofield, Medieval London houses (New Haven and London: Yale University Press, 1995), 106.

21 MS 7110, f. 4v.

22 Duffy, The stripping of the altars, 451-455; Herbert, The history of the twelve great livery companies, vol. 1, 113-115. 
political and social bodies, and their built environments, thrived. The craft guilds and their company halls continued to be important arenas for establishing and upholding post-mortem reputations and social memory, and guildsmen continued to give material gifts (including plate, textiles and furniture), as a focus or prompt for remembrance. As in the pre-Reformation era, objects were given for the performance of specific rituals; masses had been abolished, but guildsmen still donated objects for use at funerals, feasts and civic processions. ${ }^{23} \mathrm{In} 1605$ for instance, ' $\mathrm{Mr}$ Richard Lockson [an armourer] and Isabell his wife gave a velvett cloth imbroidered to bee used att ye buriall of any of ye assistants or livery of ye [Armourers'] Company'. ${ }^{24}$ Court minutes and accounts from across the London companies show that the funeral and burial of a guildsman continued to be a communal responsibility. A guildsman's coffin would be draped with the company hearse cloth, some of which were adapted late-medieval survivals, and members were urged to witness the burial, attend the sermon or hear the preacher, and subsequently participate in the memorial drinks or dinner in the livery hall, in his honour. ${ }^{25}$ In their last wills and testaments, prominent guildsmen provided funds for such occasions of remembrance (and no doubt sociability), and some bequeathed plate specifically for use at the table; at their memorial dinner and during subsequent rites of commensality. At his death, David Gitting, a member of the Vintners' Company, left a relatively humble ceramic pot with silver mounts to his guild, with the following inscription: 'Thank David Gittings for yis [this]. Think and thank. 1563'. A senior member of the Skinners' Company, William Cockayne, bequeathed one hundred and twenty pounds for the making of five silver cups in the shape of cockerels, for use at guild election dinners at the feast of Corpus Christi. The novel

23 Vanessa Harding, 'Choices and changes. Death, burial and the English Reformation', in David Gaimster and Roberta Gilchrist (eds.), The archaeology of Reformation 1480-1580 (Leeds: Maney, 2003), 386-98, there 387 , 'many of the characteristics and accompaniments of the pre-Reformation rite continued to hold their (social) value both for the dying and for their survivors'.

24 Armourers' and Brasiers' Company, 'Will and gift Books', MS 12105, f. 17, Guildhall Library, London.

25 Guildsmen were also required to attend these commemorative events in the appropriate apparel. In 1567 for example, the carpenter Thomas Harper was fined $12 \mathrm{~d}$ for 'comyng in a wronge lyverie gowne at the buryall of Mr Trull' (Edward B. Jupp, An historical account of the worshipful company of carpenters of the city of London (London: W. Pickering, 1848), 141). 
design, playfully based upon his family name, created an unforgettable connection between the guildsman and his gifts. ${ }^{26}$

Guildsmen also frequently made bequests of silver, engraved with their familial arms and inscriptions that spoke of fraternal love and memorialisation. In $1630 \mathrm{Mr}$ Warden Leadam presented to the Goldsmiths' court a great standing cup and cover, with his own arms and that of the company engraven upon it and the inscription that: "This guifte I leave amongst my friends, Of that which God did give, That when I dye this guifte of myne Amongst my friends may live'. ${ }^{27}$ Two years later Mr Avenon, another goldsmith, also donated a silver cup and cover, with an inscription that clearly anticipated the convivial context in which the gift would operate: 'When at your Hall doth shine with plate, And all your dishes served in state, When mirth abound, and wine is free, then (freely drinking) think on me'. ${ }^{28}$ Through the use and display of such objects at guild feasts and dinners, 'amongst my friends', there must have been a very real sense that the memory of the deceased was revived, and that the community of guildsmen thus extended beyond the living, present company. ${ }^{29}$ Though plate collections were on occasion melted down or sold for the inherent value of the material during particularly acute financial crises, guilds might record crucial details before sale or destruction, which would subsequently be re-inscribed on new pieces of silver when the economic climate improved, thus preserving the memory of donors. ${ }^{30}$

If the Reformation had swept away the significance of memorialisation as a social process, which ensured intercessory activities of the living fraternity on behalf of the souls of the deceased, then how might we interpret the guildsman's continued desire to be remembered within mercantile and artisanal communities? It has been proposed that within reformed society at large, the memorialisation of individuals became focused upon Christian virtues, particularly charitable endeavours; thus we see a cultural shift 'from the active memory of the dead toward charity for

26 Philippa Glanville, Silver in Tudor and early Stuart England. A social history and catalogue of the national collection, 1480-1660 (London: Victoria and Albert Museum, 1990), 335. Unusually, these cups were permanently retained by the guild.

27 Walter Sherburne Prideaux, Memorials of the Goldsmiths' Company, 2 vols. (London: Eyre \& Spottiswoode, 1986-87), vol. 1, 150.

28 Ibid., $156-157$.

29 Sheila Sweetinburgh, 'Remembering the dead at dinner-time', in Tara Hamling and Catherine Richardson (eds.), Everyday objects. Medieval and early modern material culture and its meanings (Farnham: Ashgate, 2010), 257-266.

30 The Drapers' Company recorded benefactors' details and inscriptions on silver before disposal of plate in the 1640s; the Goldsmiths' Company in the 1630 s and 1660 s. 
the living'. ${ }^{31}$ Nigel Llewellyn has demonstrated that funeral monuments in post-Reformation England-objects which perpetuated the presence of the dead in the social and political communities of their descendantsno longer sought supplication, but rather demonstrated the deceased's achievements and exhorted observers to follow his godly example. ${ }^{32}$ In relation to the London guilds in particular, Ian Archer has convincingly suggested that the 'arts and acts of memorialisation' in the later sixteenth and seventeen centuries were focussed upon the recollection of charitable activities and accomplishments of the company elite: 'a spur to further charitable endeavour' and an affirmation or legitimation of 'a set of unequal power relations'. ${ }^{33}$ Within their company halls, guildsmen were repeatedly reminded of the benevolence and generosity of politically prestigious, dead brothers: their wills were recited on quarter days; their gifts were inscribed upon wooden tables, mounted upon company walls; their donations recollected at feasts and at sermons. ${ }^{34}$ At his death in 1566, Sir Martin Bowes-a hugely significant figure in life, who had repeatedly served as Master of the Goldsmiths' Company and once as Lord Mayor of London-left funds to his guild for an annual sermon and distribution of alms to the poor at St Mary Woolnoth, to be followed by a memorial feast in the Goldsmiths' Hall. ${ }^{35}$ In his last will and testament, drawn up in 1565 , Bowes also decreed that over thirty close family members and guild associates were to each be given a gold mortality ring of his own design, 'with two bowes bent and a deaths hedd graven between them ... with the inscripture about it "Remember the end"'. ${ }^{36}$ Guildsmen clearly wished to be remembered as benevolent, civic philanthropists; but within organisations whose primary purpose was the regulation of the craft or trade, and whose memberships were largely composed of working artisans, identity

31 Peter Sherlock, 'The reformation of memory in early modern Europe', in Susannah Radstone and Bill Schwarz (eds.), Memory. Histories, theories, debates (New York: Fordham University Press, 2010), 30-40, there 33.

32 Nigel Llewellyn, Funeral monuments in post-Reformation England (Cambridge: Cambridge University Press, 2000), 255-256; Peter Sherlock, Monuments and memory in early modern England (Aldershot: Ashgate, 2008), 97-127.

33 Ian Archer, 'The arts and acts of memorialization in early modern London', in Julia F. Merritt (ed.), Imagining early modern London. Perceptions and portrayals of the city from Stow to Strype, 1598-1720 (Cambridge: Cambridge University Press, 2001), 89-113, there 9o; Robert Tittler, 'Portrait, precedence and politics amongst the London liveries c. 1540-1640', Urban History 35 (2008), 349-362, there 356.

34 Archer, 'The arts and acts of memorialisation', 95-102.

35 Ibid., 101-102.

36 PROB 11/49, The National Archives, Kew. 
and memorialisation were also associated with one's virtuosity (in life) as a master craftsman. Further, this feature of commemoration-embodied in material things, and displayed in guild halls_-remained constant across the Reformation divide.

In 1567 , the armourer John Kelte was at the peak of his professional career: he had been selected to become a liveryman of his guild and he had achieved the honour of being appointed Master Workman at the royal armour workshops at Greenwich, the first English armourer to have been selected for this role since the royal workshops had been established by Henry VIII over fifty years before. ${ }^{37}$ At the election feast in that same year, Kelte presented his fellow guildsmen with a gift, carried on a platter to the high table before the multiple dishes of food: a miniature harness in the latest Greenwich armoury style, upon a wooden sculpture of St George, referred to as the 'George of compleat armo[u]r on foote' in the court minutes. ${ }^{38}$ Unfortunately this object is no longer extant; there are few material survivals from London guilds as a result of repeated fire and flood damage to company buildings. However another such model does survive from earlier in the century, for when Kelte presented his material gift to the Armourers' guild, another miniature sculpture of St George, fitted with steel armour, was displayed in the company Hall 'over the [hall] skrein [screen]' ${ }^{39}$

Forty years before Kelte gave his gift, the armourer William Vynyard had presented his guild with a polychromed oak sculpture of their patronal figure St George, clothed in a miniature suit of armour which had been crafted in the donor's own workshop. ${ }^{40}$ The Armourers' 'Benefactor's book', compiled in the 1660 s as a retrospective account of material gifts to the guild, demonstrates that the sculptural offering of William Vynyard, in 1528, was clearly intended to be part of the company's larger visual and material culture of religious devotion, civic honour and personal commemoration, housed within the Armourers' Hall on Coleman Street in the City of

\footnotetext{
37 Glover, Men of metal, 39.

38 Armourers' and Brasiers' Company, 'Inventories', MS 12107, f. 2r, Guildhall Library, London.

39 Armourers' and Brasiers' Company, 'Court minutes', MS 12071/2, f. 475v, Guildhall Library, London.

40 It is hard to ascertain why this sculpture of St George has survived to the present day; whereas almost all other pre-Reformation sculptures in England (including hundreds of this popular saint), were destroyed in waves of iconoclasm throughout the early modern era. It is possible that through its prominent role in the convivial recreations and civic representations of the guild, and its relocation to the Armourers' hall screen, its devotional associations were defused.
} 
London, a 'theatre' or 'site of memory' ${ }^{41}$ All the gifted items and furnishings for the Armourers' Hall, crafted by a range of artisans within the city, were no doubt expected to act as lasting embodiments of the donors' generosity, political influence and devotional piety; but the saintly sculpture given by Vynyard had a more nuanced symbolic value, for it represented the Armourers' patronal saint in the material and form in which the guildsmen themselves were familiar and skilled. ${ }^{42}$ In 1428, John Amflesh, who had been Master of the guild in the previous year, gifted to his guildsmen 'the hallyngs to the high deysse' [dais], an impressive set of 'steyned' or painted textiles, hung at the high end of the communal hall, which combined a visual representation of St George with celebratory textual verses by the poet John Lydgate. ${ }^{43}$ In the same year, two senior guildsmen 'gave the crest of the high deyesse with three angells', a wooden carving which framed the impressive textile, and the high table, below. ${ }^{44}$ Nearly a century later, in 1522 , with 'the hallyngs' still prominently displayed, Master of the Armourers' Company, John Alleyn, gave 'a table of joyners worke with the picture of St George upon it in vellom'. ${ }^{45}$ Significantly, when William Vynyard presented his St George sculpture to the Company, in that same decade, accompanied with 'a Lattin candlestick that is before it', he also fashioned the broader architectural and material context in which the figure might operate, including all 'the lattice [work] that be about the galleryes into the [hall] Chamber' ${ }^{46}$ The guild's annual commemoration of St George's Day, a great convivial event celebrated throughout the sixteenth and seventeenth centuries - which started with a mass, or a sermon from the 1570s-and whose highlight was the extravagant feast, hosted in the Armourers' Hall, would have been the moment when the sculpture and other material representations of their saintly patron performed to best effect. The figurative representation of St George also had a social or ritual life when the guildsmen presented their craft outside the Hall in a wider civic context, as for example when the company travelled

41 Pierre Nora, 'Between memory and history. Les lieux de memoire', Representations 26 (1989), 7-25; Archer, 'The arts and acts of memorialisation', 9o. The Armourers do not make it clear why this retrospective account was made at this date. It might have been related to the recent Restoration of the English monarchy (in May 1660).

42 The gifts are recorded from the later 1420s; from the acquisition of their communal hall at the northern end of Coleman Lane, in the City of London.

43 MS 12105, f. 2.

44 Ibid.

45 Ibid., f. 9 .

46 Ibid., f. 10. 
by boat to Greenwich in 1540, to celebrate the marriage of Henry VIII to Anne of Cleves, with 'banners, targets and our George standing over the rails' ${ }^{47}$ During the annual civic processions and theatrical performances of the Midsummer Watch and Lord Mayor's Show, the Armourers' sculpture of their patron saint might also have taken a prominent place in the company's pageant display. 48

Standing at just under a meter high, $(84.5 \mathrm{~cm})$, William Vynyard's figure of St George, his horse and their reptilian adversary were carved in the $15^{20}$ from a single piece of English oak. ${ }^{49}$ Dragon and visible elements of the Saint and his steed were polychromed, an entirely typical decorative feature of contemporary devotional sculpture. ${ }^{50} \mathrm{~A}$ sense of material veracity was achieved through the incorporation of genuine hair for the horse's tail, textiles for the saddle, studded leather for the reins and most strikingly of all, the perfectly proportioned full plate iron armour for man and horse. That the style of armour was intended to be that commissioned and worn for a joust or tournament is suggested by the broken lance on the base of the statue and gripped in the dragon's claws, as well as the reinforced left pauldron or shoulder-plate. Significantly, the suit was crafted by William Vynyard according to contemporary continental fashions for armour; the waistline is pinched (as stressed by a copper belt), there is an emphasis upon the commanding upper body (achieved through vertical ridges running down the breastplate), and the figure's sabatons or shoes are squared-toed, a clear contrast to the long tapering footwear which had been fashionable in the previous century. ${ }^{51}$ These traces of stylistic and technical engagement with Italian fashions, the centre of quality armour production in late-medieval Europe, would undoubtedly have been interpreted by an organisation of skilled metalworkers as an unambiguous statement of Vynyard's personal artisanal virtuosity. An impression which would have been heightened by the scale of the suit; differing from a full-sized armour simply in having its articulated parts made solid. ${ }^{52}$

47 Glover, Men of metal, 43-44.

48 Michael Berlin, 'Civic ceremony in early modern London', Urban History Yearbook 13 (1986), 15-27; Anne Lancashire, London civic theatre. City drama and pageantry from Roman times to 1558 (Cambridge: Cambridge University Press, 2002), 153-184.

49 Karen Watts, 'The arts of combat', in Richards Marks and Paul Williamson (eds.), Gothic art for England 1400-1547 (London: V\&A Publications, 2003), 192-208, there 199.

50 Michael Baxandall, The limewood sculptors of renaissance Germany (New Haven and London: Yale University Press, 1980), 48.

51 Angus Patterson, Fashion and armour in renaissance Europe. Proud lookes and brave attire (London: V\&A Publications, 2009), 33-35.

52 Watts, 'The arts of combat', 198. 
Miniaturised armour, as distinct from that made for young boys or adolescents, was a very rare spectacle in early modern Europe. The technical skills required for such an intricate assemblage of metalwork would have no doubt evoked curiosity or wonder. In this respect it is pertinent that Vynyard made such a material testimonial of his personal masterly skills in precisely the same era as the creation of the royal armour workshops at Greenwich, a centre established by Henry VIII for the production of impressive, bespoke tournament suits, by highly skilled Italian, Flemish and 'Almain' armourers. ${ }^{53}$ The presentation of miniature armour by the Master of the indigenous guild and subsequently the Master of the Greenwich workshops - by Vynyard in 1528 and Kelte in 1567 - must have thus been a substantial symbolic statement regarding the ability of English armourers to create customised suits themselves. The continued presence (and addition) of these armoured sculptures suggest that the association of their craft and personal memory with religious honour and antiquity was a valued cultural motif within the early modern guild.

Across late medieval and early modern Europe, armour, in general, was understood to be a hugely important statement of a man's taste, affluence and identity in life - as exemplified by the numerous portraits of kings and aristocrats posturing in their made to measure suits-as well as a particularly suitable artefact for ensuring that one endured as a figure of historic significance after death; a lasting shell which physically embodied personhood, perhaps even spirit. At the funeral of the Prince of Wales, heir to the English throne, in 1502, a knight clad in Arthur's own armour led the funeral procession; over a century later, Christian II, Elector of Saxony (1591-1611) had a loyal squire wear his bespoke armour at his own funeral, 'in effigie'. ${ }^{54}$ In both cases, the desired effect must have been for the customised armour-in motion-to suggest the continued presence of the 'political body' of the deceased. In his castle at Ambras, Ferdinand II, Holy Roman Emperor (1619-1637) had a specially constructed Rustkammer, a collection of arms and armour that had formerly been owned-and worn-by famous men. Decades after they had been crafted and donated (and their makers had passed into the illustrious community of deceased

53 Thom Richardson, 'The royal armour workshops at Greenwich', in Graeme Rimer, Thom Richardson and J.P.D. Cooper (eds.), Henry VIII. Arms and the man, 1509-2009 (Leeds: Royal Armouries, 2009), 148-154.

54 Llewellyn, Funeral monuments, 95; Heinz-Werner Lewerken, 'The Dresden armory in the new stable', in Dirk Syndram and Antje Scherner (eds.), Princely splendor. The Dresden court, 1580-1620 (Milan: Electa; Dresden: Staatliche Kunstsammlungen, 2004), $70-79$, there 79 . 
benefactors), Vynyard and Kelte's sculptures might have embodied both the presence of patron saint within the institutional home of his guildsmen and the skilled identity of the masterly armourers themselves. Inventories of communal possessions reveal that from the later decades of the sixteenth century, prominent men associated with the Armourers' Company had their (full-sized) suits displayed in the Armourers' Hall, along a specially constructed semi-public gallery. ${ }^{55}$ Within a space dedicated to the operation of the craft, this collection of suits represented the close connections between memorialisation of prominent members and the highly skilled practices of the associated artisanal practitioners.

In the early 1570 , several senior members of the Carpenters' Company of London commissioned a series of four wall paintings for the decoration of the dais end of their communal Hall, a building which was situated on London Wall, a short distance from the Armourers' institutional headquarters. ${ }^{56}$ The paintings — three of which are still extant - approximately three foot high and twenty-three foot in length, were applied directly onto plaster and were organised as a coloured narrative frieze, with each image framed and separated from the others by a classically-inspired architectonic border. The paintings depict the crucial role of carpentry throughout Old and New Testament biblical history: Noah receiving the command of God for the construction of the ark, and his three sons at work (Genesis 6:9-22); King Josiah ordering the rebuilding of the Temple at Jerusalem (2 Kings 22:1-7); Jesus (and Mary) loyally observing Joseph at work as a carpenter (Luke 2:41-52) and Jesus, 'the carpenter's son', teaching in the synagogue (Matthew 13:53-58). ${ }^{57}$ Each image is accompanied by the associated biblical verse in a black letter inscription; the clear emphasis on the 'process of a story', perhaps a self-conscious attempt to avoid allegations of idolatry. ${ }^{58}$ In three of the frames, full-bearded senior male figures are featured wearing contemporary livery dress of the $1560-70$ - - with distinctive blackcap and fur-trimmed gown-alongside those dressed in 'traditional' biblical costume. It is probable that these liverymen were likenesses of the commissioners of the paintings, and thus the guildsmen in question were immortalised in these historic narratives alongside senior

55 MS 12107, f. 6r.

56 Jupp, An historical account, 239.

57 All references from The Geneva Bible (1560).

58 Tessa Watt, Cheap print and popular piety, 1550-1640 (Cambridge: Cambridge University Press, 1991), 209. 
biblical figures. This personal inclusion within the mural was an enterprising means of establishing individual authority and memory within a broader visual statement about communal craft identity. Such a personal rendering within a wider pictorial narrative would also have alluded to the guild tradition, throughout late-medieval Europe, of patronal representation within ecclesiastical fixtures such as stained glass and altarpieces. ${ }^{59}$

Crucially, these wall paintings marked a significant event in the communal life of the guild, as they were commissioned by the liverymen at the beginning of a substantial rebuilding project: the paintings were undertaken at the same time as the dais end of the internal hall was wainscoted and a wood panelled gallery was also established. Within the next twenty years a new parlour had been built, a counting house was constructed and the internal hall was substantially enlarged 'at the east ende'. ${ }^{60}$ The paintings were thus not simply an isolated visual statement about the genealogy of the carpenters' craft but were themselves an integral element of the new built environment. The visual representations of reconstruction or rebuilding were highly apposite at a time of structural remodelling, and must have drawn attention to the surrounding materiality of the new Carpenters' Hall: the wood panelling in particular. In an age in which boundaries between 'wall' and 'painting' were yet to be precisely defined, a narrative history of the craft of carpentry had become literally embedded in the built fabric of the Carpenters' Hall, and memorialisation of eminent guildsmen inseparable from collective physical structures. ${ }^{61}$ Thus in the case of the Carpenters' Company, their newly modelled guild hall was itself the artisanal masterpiece, and interior decorative features drew attention to the senior craftsmen who had undertaken the rebuilding project and commissioned the wall paintings.

When the aforementioned armourer William Vynyard died in 1535, he bequeathed to his guild both his workshop tools-his anvil and plate shears - and enough money for the wardens and yeomanry to host a substantial 'drinking' in his honour; a memorial which would have taken place in their Hall, in the presence of Vynyard's figurative sculpture of

59 Duffy, The stripping of the altars, 163.

60 Carpenters' Company, 'Wardens' Accounts 1592-1622', MS 4326/6, f. 42r, Guildhall Library, London.

61 Juliet Fleming, Graffiti and the writing arts of early modern England (London: Reaktion, 2001), 32; Lucy Gent, 'The Rash Gazer': economies of vision in Britain, 1550-1660', in Lucy Gent (ed.), Albion's Classicism. The visual arts in Britain, 1550-1660 (New Haven and London: Yale University Press, 1995), 377-393, there 382. 
St George. ${ }^{62}$ Among prominent master craftsmen, Vynyard was not unusual in bestowing his personal artisanal tools to his guild, objects which embodied a lifetime of accumulated artisanal knowledge, experience and skill, and which appear to have been displayed within company buildings. At his death, in the mid sixteenth century, the armourer William Seger gave 'to the clothing [the liverymen] thirteen shillings fower pence to the yeomanry tenn shillings and to the hall a great biccorne [an anvil] and a paire of great sheires'. ${ }^{63}$ Members of the Pewterers' Company frequently donated workshop moulds to their guild, objects of considerable value, which were subsequently stored in the guild counting house or treasury alongside charters, wills and silver plate. ${ }^{64}$ Master masons routinely bequeathed workshop tools or instruments, building 'plots' or plans, designs and books: a 'cumulative resource' which represented erudition, craft knowledge and the sustained identity of the craft practitioner ${ }^{65}$ Significantly, when master craftsmen were depicted in portraiture from the later decades of the sixteenth-century-visual representations which were displayed in prominent chambers within guild halls - they were sometimes shown with their artisanal tools. ${ }^{66}$ A posthumous portrait of the master carpenter William Portington-former Master of the Carpenters' guild and royal Master Carpenter for half a century, from 1579 to $1629-$ presented this hugely accomplished artisan with the tools of his craft, dividers and ruler, in his hands. ${ }^{67}$ Based upon an original painting of 1626 , commissioned by Portington himself, this 1637 version was-according to a textual inscription at the base of the portrait-commissioned for display in the Carpenters' Hall, by another carpenter, Matthew Bankes, 'who served him 14 years'. ${ }^{68}$ The representation of this great guildsman with his workshop tools was a clear visual memorial of Portington's artisanal skills and achievements in life and his continued connection to the living arti-

62 Glover, Men of metal, 45.

63 MS 12105 , f. 11.

64 MS 7110, f. 13v.

65 John Summerson, 'Three Elizabethan Architects', Bulletin of the John Rylands Library 40 (1987), 202-228.

66 Robert Tittler, The face of the city. Civic portraits and civic identity in early modern England (Manchester: Manchester University Press, 2007), 150-154.

67 Anthony Gerbino and Stephen Johnston (eds.), Compass and rule. Architecture and mathematical practice in England, 1500-1750 (New Haven and London: Yale University Press, 2009), 63 .

68 Tarnya Cooper, Citizen portrait. Portrait painting and the urban elites of Tudor and Jacobean England and Wales (New Haven and London: Yale University Press, 2012), 197. 
sanal community (including the commissioner, Bankes) who had trained within his workshops.

In late medieval and early modern London the livery halls were hugely significant sites for the memorialisation of eminent members. Through the donation of material artefacts to company buildings-and their subsequent use in the rites of the guilds-merchants and master craftsmen were able to shape their post-mortem reputations and legacies. Their material bequests reveal complex memory cultures, within which a wide range of qualities and achievements were valued. Guildsmen wished to be remembered as affluent charitable benefactors and men of honour, who comprehended the importance of company customs and the illustrious histories and patrons of their companies; they presented themselves as perpetual participants in convivial rituals and crucially, as masters of their respective artisanal practices. Though the break with Rome and discrediting of Purgatory undermined the traditional intercessory observances of living brothers on behalf of deceased members, later generations of guildsmen never forgot their fraternal obligations to remember their benefactors and uphold the reputations of the dead in the community of the living company. 